hieromtrent de meening der Vergadering vernemen. Na eenige gedachtenwisseling wordt de Secretaris gemachtigd het feestnummer in de Nederlandsche taal uit te geven, met vrijlating echter aan de schrijvers, om, als zij dit verlangen, hunne bijdragen in eene vreemde taal in te zenden.

Door den Secretaris wordt verder ter tafel gebracht een schrijven van het Comité tot regeling van het zesde internationale Congres der Orientalisten, houdende uitnoodiging dat het Instituut van zijne belangstellende medewerking doe blijken ter bevordering van het beoogde doel.

Na gedachtenwisseling wordt besloten het Comité te antwoorden, dat het verzekerd kan zijn van de belangstelling en medewerking van het Instituut, en te eer, waar het blijkt, dat bij het Congres de talen en ·volken van Ned. Indië eene hoofdplaats zullen innemen; gaarne wil het Instituut zich als lid doen inschrijven; ter gelegener tijd zal het Bestuur mededeeling doen van de namen van hen, die het op het Congres zullen vertegenwoordigen, terwijl het, voor zoover het in zijn vermogen is, wil medewerken om de zittingen belangrijk te maken en het verblijf der congresleden hier te lande te veraangenamen zoowel door de openstelling ten hunnen behoeve van de lokalen der instelling als door het verstrekken van de noodige hulp en inlichtingen, zoo wellicht de residentie met een bezoek der Congresleden mocht worden vereerd.

Door den heer van Musschenbroek worden eenige mededeelingen gedaan omtrent de door inlanders vervaardigde kaarten, waaraan in de vorige Vergadering herinnerd was en omtrent wier bestaan men gaarne nadere inlichtingen zou ontvangen.

$\mathrm{Na}$ eenige gedachtenwisseling wordt besloten het medelid Raden Ismangoen Danoe Winoto, thans te Probolinggo, uit te noodigen omtrent het al of niet bestaan der bedoelde kaarten een onderzoek in te stellen, waartoe de heer van Musschenbroek zich bereid verklaart eene korte nota samen te stellen.

Op voordracht van den heer Quarles van Ufford wordt als lid aangenomen Jhr. Mr. W. C. A. Elout van Soeterwoude, te 's Gravenhage.

Niets meer hierna aan de orde zijnde, wordt de Vergadering door den Voorzitter gesloten. 


\section{4TE BESTUURSVERGADERING,}

GEHOUdEN 19 MeI 1883.

Tegenwoordig de heeren Kern (Voorzitter), Kniphorst (Penningmeester), Humme, van Deventer, Niemann, Juynboll, Bool, van Musschenbroek, Matthes en Wijnmalen (Secretaris). Afwezig, zonder kennisgeving, de heeren Weitzel en Quarles van Ufford.

De notulen van het verhandelde in de vorige bijeenkomst worden gelezen en goedgekeurd.

Door den Secretaris-Bibliothecaris wordt vervolgens medegedeeld met welke werken, 't zij door geschenken, 't zij door aankoop, de boekerij weder is vermeerderd geworden, waarbij tevens wordt voorgelezen een schrijven van het medelid C. A. Aeckerlin, te Benkoelen, ten geleide van een afschrift van en eenige inlichtingen omtrent een in 1821 to Londen gedrukt Maleisch boek, bevattende "A code of laws as established by the Pangerans court at Fort Marlborough collected by Henry Robert Lewis Esq., of the Bencoolen civil service, and late Magistrate." Voor dit geschenk zal de dank der Vergadering worden betuigd.

Voorts zijn ingekomen missives:

10. van de Koninklijke Akademie van Wetenschappen, te Amsterdam, houdende dankbetuiging voor de toegezonden 3e aflevering der Bijdragen, dl. II, 4e reeks.

20. van de heeren Mr. F. B. Coninck Liefsting, te 's Gravenhage, en J. J. H. Schulz, te Manna, houdende kennisgeving van de aanvaarding van het lidmaatschap van het Instituut.

Beide missives worden voor kennisgeving aangenomen.

T'er tafel wordt gebracht een schrijven van den hoogleeraar, waarn. Voorzitter van den Raad van bestuur der Instelling voor onderwijgs in de taal-, land- en volkenkunde van Ned. Indië 